\title{
Communication Style and Looks Healthy
}

\author{
Dr. Ulani Yunus \\ (Study Program of Marketing Communication / Bina Nusantara University, Indonesia)
}

\begin{abstract}
This study uses explanative survey about ethos communicator (lecturers of Institute of Technology and Business Kalbe/ ITBK Jakarta). Data will be tested with the statistic using SPSS to find the Pearson product moment coefficient. The number of respondents 83 people. The results of the study found: professional lecturers need to be equipped with the ability to "present themselves" as well as cognitive ability. There is relationship between communication style with looks healthy in the classroom.
\end{abstract}

Keywords: Communication Style, Lecturer, Healthy, Behavior.

\section{Introduction}

When lecturers teach students, they are properly issued abilities and expertise in the field they lecturing to create a favorable atmosphere for himself and his students became his prestige. With its seriousness will build the perception that benefits themselves, because the students believe what they taught by lecturers. In addition for the students, there are other skills of lecturers for the purpose in the learning process successful, such as the attraction owned lecturer in psychology called interpersonal attraction. The ability of lecturers, student trustworthiness called credibility, attractiveness lecturer known as the attraction and power of lecturers: in this study of communication is called communication style. Lecturer is a special figure that seems real to the students, the lecturer's behavior that shows his/her physically need to be considered in order to create a positive perception. Based on these conditions, this study aims to find out how close relationship between credibility, attraction and power of lecturer with the healthy behavioral in the classroom?

\section{Hypotheses :}

Hypothesis Null $(\mathrm{H} 0)=$ There is no significant relationship between communication styles of lecturer with students' perceptions of looks healthy lecturer.

Hypothesis of Research ( $\mathrm{H} 1)$ = There is a significant relationship between communication styles of lecturer with students' perceptions of looks healthy lecturer .

Above hypotheses is decomposed into sub hypotheses: 1. There is a significant relationship between the credibility of lecturer with students' perceptions of looks healthy lecturer 2. There is a significant relationship between the attractiveness / attraction of lecturer with students' perceptions of looks healthy lecturer 3 . There is a significant relationship between power of lecturer with students' perceptions of looks healthy lecturer.

\section{The Method}

Data collected by distributing questionnaires to selected respondents which is the students of the Institute of Technology and Business Kalbe (ITBK) as many as 83 people out of a population of 500 people. Determination of the number of samples using Taro Yamane formula (Sarjono and Julianita, 2011). Reliability testing using Cronbach Alpha performed. Cronbach Alpha calculation utilizing SPSS, the critical limit for the Alpha value indicates a reliable questionnaire was 0.60. (Nunnally, 1967 in Ghozali, 2006). Meanwhile, to test the hypothesis used statistically by looking at the numbers Pearson product moment correlation coefficient.

\section{Discussion}

The lecturers when teaching students proper issuing capabilities and expertise in the field they teach to generate a favorable atmosphere for themselves and their students. With its seriousness will create the perception that benefits themselves, because the students believe what they discussed / taught by lecturers. In addition to the student ability and confidence, there are also other skills of lecturers for the purpose in the learning process successful, such as the attraction owned lecturer in psychology called interpersonal attraction consisting of: physical attractiveness, reward, familiarity, closeness (proximity) or, ability (competence). (Rakhmat: 2001). Besides the four factors above, there is one more factor that is power of lecturer in class. The power in question is how well teachers can lead the students. It is atmosphere or conditions created lecturer in class, it happens when the interaction between lecturer and students created in such a way that lead to enjoyment and understanding of the discussion of the course material. 
Basically, communication is used to create or enhance the relationship between human activity or group. Type of communication consists of:

1. Verbal communication with words

2. Non verbal communication is called body language

Verbal communication will depend on vocabulary. Communications will be effective when the message conveyed by the words. Non-verbal communication consists of: Facial expressions, eye contact, touch, posture, voice and gestures. All communication behaviors above, will lead to the perception of the health of a person. For example: If he coughed frequently when talking or walking without the spirit, the behavior will convey the message that he or she had health problems. Very fine nuances in teacher behavior-many of which are nonverbal, uncontrollable, unconscious, and often undetected in natural observation - seem to have substantial, accumulating effects on students. (Babad, Bernieri and Rosenthal, 1991)

The prior research communication style has been done on title "Relationship between Communication Style with Student's Academic Achievement (Correlation Studies Teacher Communication Style with Students' Academic Achievement at Junior High School in Pakem Yogyakarta - Indonesia)". The results of the analysis conclude that there is a significant relationship between teacher communication styles with students' academic achievement. So the theory is used in this study proved and showed that good communication and style appropriate for students will assist students in improving academic achievement. (Kurniati, 2012).

This research will be measured by style of lecturer communication in the classroom and lecturer behavior looks health concerned. Here are the results of research and discussion:

\subsection{Lecturer Communication Styles In The Classroom}

Indicators to measure the lecturer communication style measured by questions relating to the four subvariables: skills and abilities in teaching, trust / honesty, attraction / attractiveness, power in the pose of submission. The data on the reliability of the results of the questions / statements to measure lecturer communication styles with variable sub skills and abilities (X1.1) lecturers shown in Table 1 below:

Table 1. Reliability Test with Indicator Skills / Ability Lecturer in The Classroom

\section{Reliability Statistics}

\begin{tabular}{|lll|r|}
\hline Cronbach's Alpha & Part 1 & Value &, 922 \\
& & N of Items & $16^{\mathrm{a}}$ \\
& Part 2 & Value &, 932 \\
& & Notal N of Items & $16^{\mathrm{b}}$ \\
& & 32 \\
Correlation Between Forms & &, 865 \\
Spearman-Brown & Equal Length &, 927 \\
Coeff icient & Unequal Length &, 927 \\
Guttman Split-Half Coefficient &, 926 \\
\end{tabular}

a. The items are: Q1, Q2, Q3, Q4, Q5, Q6, Q7, Q8, Q9, Q10, Q11, Q12, Q13, Q14, Q15, Q16.

b. The items are: Q17, Q18, Q19, Q20, Q21, Q22, Q23, Q24, Q25, Q26, Q27, Q28, Q29, Q30, Q31, Q32.

\section{Source: Adapted from the research}

After testing the reliability and validity of the questions / statements submitted, it is evident that a reliability coefficient to measure the value of the indicator on the first part of the independent variable (X1.1) on the question of part 1, Cronbach's Alpha is 0.922 and the questions part 2, its Cronbach's Alpha is 0.932. This shows that for questions 1 to 16, the whole question is declared reliable. Questions in the questionnaire are expressed as a convincing instrument (excellent) for research. It appears that rxy $=0856$ and the resulting reliability values $\operatorname{rxx}{ }^{\prime}=0,927$. With this level of correlation rxy 0.865 , also shows a very strong correlation. 
Table 2. Reliability Test with Indicator Trust / Honesty Lecturer

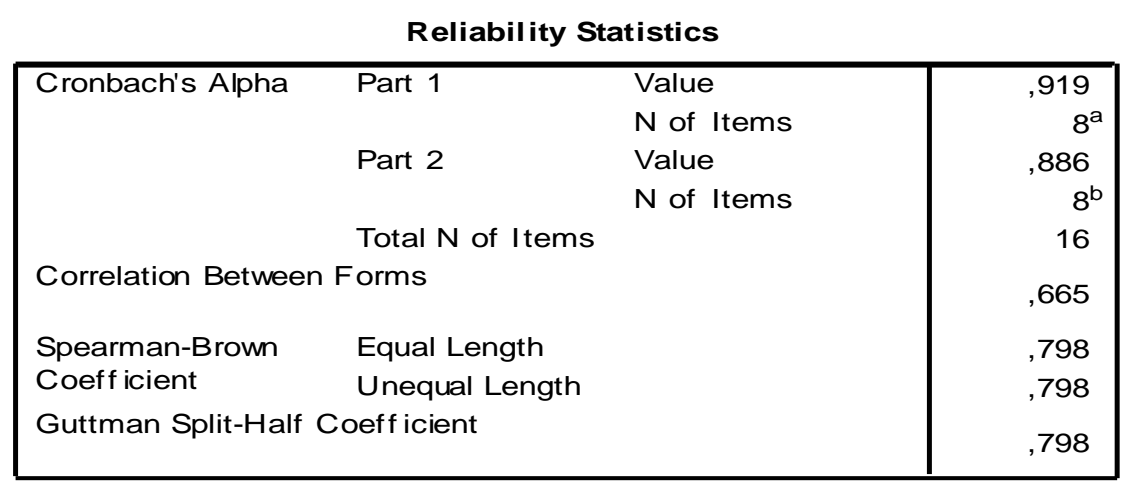

a. The items are: Q17, Q18, Q19, Q20, Q21, Q22, Q23, Q24.

b. The items are: Q25, Q26, Q27, Q28, Q29, Q30, Q31, Q32.

Source: Adapted from the research

Reliability coefficient for the indicator measuring the variables of the second part (X1.2) showed the Cronbach's Alpha of 0.919 in the first and second Cronbach's Alpha of 0.886 . Thus the reliability of questions to measure the indicator on the X1.2 is at excellent levels. Correlation between the hemispheres were calculated using the product moment correlation. It appears that $\mathrm{rxy}=0665$ and the resulting reliability values $\mathrm{rxx}^{\prime}=0798$.

The statistical test of the level of correlation, the highest was in question no 27 with a correlation coefficient of 0.761 . the statement about the sincerity of the lecturer. This is an interesting phenomenon in today because in the metropolitan cities of sincerity is considered rare, but in ITBK students' perspective is different. Lowest coefficient was in questions is no 32 which is less bold statement reprimanding the lack student. That is, the lecturer do not hesitate to reprimand students ITBK who ignoring the class, even if it is less preferred by students but this action is recognized as the right thing to be done by the lecturer while teaching.

To rate physical attractiveness / attraction measured lecturer is in Table 3 below:

Table 3. Reliability Test with indicators lecturer attractions when teaching

Reliability Statistics

\begin{tabular}{|lll|r|}
\hline Cronbach's Alpha & Part 1 & Value &, 907 \\
& & N of Items & $8^{\mathrm{a}}$ \\
& Part 2 & Value &, 842 \\
& Total N of Items & & $8^{\mathrm{b}}$ \\
Correlation Between & Forms & 16 \\
Spearman-Brown & Equal Length &, 763 \\
Coeff icient & Unequal Length &, 866 \\
Guttman Split-Half Coeff icient &, 866 \\
& &, 866 \\
\hline
\end{tabular}

a. The items are: Q33, Q34, Q35, Q36, Q37, Q38, Q39, Q40.

b. The items are: Q41, Q42, Q43, Q44, Q45, Q46, Q47, Q48.

Source: Adapted from the research

The result of data through SPSS showed that Cronbach's Alpha for lecturers appeal amounted to 0.907 part 1 and part 2 question, its Cronbach's Alpha is 0.842 with as many questions as 8 pieces. While rxy $=0763$ and the resulting reliability values $\mathrm{rxx}{ }^{\prime}=0866$. It also shows that the correlation is very strong.

Furthermore, it is interesting from a number of questions in this study is that the attractiveness of ITBK' lecturer highest correlation coefficient values are in question no 37 is dressed in matching. This suggests the perception of ITBK' students that lecturers have a habit of dressing to match. 0.471 is the correlation coefficient of this variable, which is in question no 48 of the properties that are less favored students, with this data, it can 
be said that the average ITBK' lecturer properties favored by students. This will affect students when learning as mentioned in the "Communication Teacher Journal". In other words, communication changes how objects are perceived and the range of potential meanings they can embody. (Keaton \& Bodie, 2011).

To test the validity and reliability of variables: Lecturer's is shown in Table 4. below:

Table 4. Reliability Test with Indicators Power Lecturer

Reliability Statistics

\begin{tabular}{|c|c|c|c|}
\hline $\begin{array}{l}\text { Cronbach's Alpha } \\
\text { Correlation Betweer } \\
\text { Spearman-Brown } \\
\text { Coeff icient } \\
\text { Guttman Split-Half }\end{array}$ & $\begin{array}{l}\text { Part } 1 \\
\text { Part } 2 \\
\text { Total N } \\
\text { Oorms } \\
\text { Equal } \\
\text { Unequ } \\
\text { oefficie }\end{array}$ & $\begin{array}{l}\text { Value } \\
\mathrm{N} \text { of Items } \\
\text { Value } \\
\mathrm{N} \text { of Items }\end{array}$ & $\begin{array}{c}, 872 \\
7^{a} \\
, 835 \\
6^{b} \\
13 \\
, 641 \\
, 781 \\
, 782 \\
, 781\end{array}$ \\
\hline
\end{tabular}

a. The items are: Q49, Q50, Q51, Q52, Q53, Q54, Q55.

b. The items are: Q56, Q57, Q58, Q59, Q60, Q61.

Source: Adapted from the research

The results of studies on the lecturer communication style at ITBK at the independent variable third (X3) that lecturers powers shows that the Cronbach's Alpha for appeal lecturer part 1 is at 0.872 and the questions part 2, Cronbach's Alpha it is 0.835 with a question as much as 13 pieces. It also makes the excellent standards for reliability. The calculation result $\mathrm{rxy}=0641$ and the resulting reliability values $\mathrm{rxx}{ }^{\prime}=0.7815$. It also suggests that the strong correlation between the variables X3 with Y. Research results found that teachers who believed they were interacting with bright students smiled and nodded their heads more than Often teachers interacting with slow students (Cooper, 1979). It is possible that the behavior of the lecturer considers fun will be more assertive, not aggressive controlled class or submissive.

ITBK's lecturers teaching in this time period showed the ability to master a class in an orderly manner, as shown by the high correlation coefficients in response to the statement in the questionnaire no 54 is equal to 0.712. Thus, the lecturer communication style has proven of the processed data is able to make the order in the classroom. While the lowest is the correlation coefficient in question no 56 is about the professors who give appreciation / rewards to students who answered correctly, the value of the correlation coefficient of only 0.402 .

\subsection{Behaviors of Looks Healthy Lecturers}

The data on the reliability of the results of the questions / statements to measure behavior of health lecturer in students' perceptions shown in Table 5 below.

Table 5. Reliability Test with Indicators Behavior of Looks Health Lecturer

Reliability Statistics

\begin{tabular}{|lll|r|}
\hline Cronbach's Alpha & Part 1 & Value &, 859 \\
& & N of Items & $9^{\text {a }}$ \\
& Part 2 & Value &, 935 \\
& & N of Items & $8^{\mathrm{b}}$ \\
& Total N of Items & & 17 \\
Correlation Between Forms & &, 694 \\
Spearman-Brown & Equal Length &, 819 \\
Coefficient & Unequal Length &, 820 \\
Guttman Split-Half Coefficient &, 805 \\
\hline
\end{tabular}

a. The items are: Q62, Q63, Q64, Q65, Q66, Q67, Q68, Q69, Q70.

b. The items are: Q71, Q72, Q73, Q74, Q75, Q76, Q77, Q78.

Source: Adapted from the research 
Results of the data on indicators of lecturer behavior of health shows that the Cronbach's Alpha for part 1 is 0.859 and the questions part 2, Cronbach's Alpha was 0.935 with a question of his total of 17 pieces. It also makes the excellent standards for reliability. The calculation result rxy $=0819$ and the resulting reliability values $\operatorname{rxx}{ }^{\prime}=0820$.

ITBK lecturers teaching this time period stated "convinced while teaching" as shown by the high correlation coefficients in response to the statement in the questionnaire No. 73 is equal to 0.787 . Thus, lecturers behavior in the class room in students perception is very good healthy. While the lowest is the correlation coefficient in question no 68 is about not reprimanded when students are not orderly, the value of the correlation coefficient of only 0.226 . That are lecturers in ITBK have the ability to reprimand the students who did not order in the classroom. In a previous study proved that the teachers-to-be must be helped to understand the connections between and among teacher beliefs about students, teacher actions in classrooms, and student outcomes. (Villegas, 2007). Lecturer in a class action will affect the quality of the students, including the attitude order.

This section describes how the relationship between the variables under study that has been tested by statistics. Once processed SPSS can result in the following:

Table 6. The Correlation between the Communication Styles with Lecturer Behavioral of Health

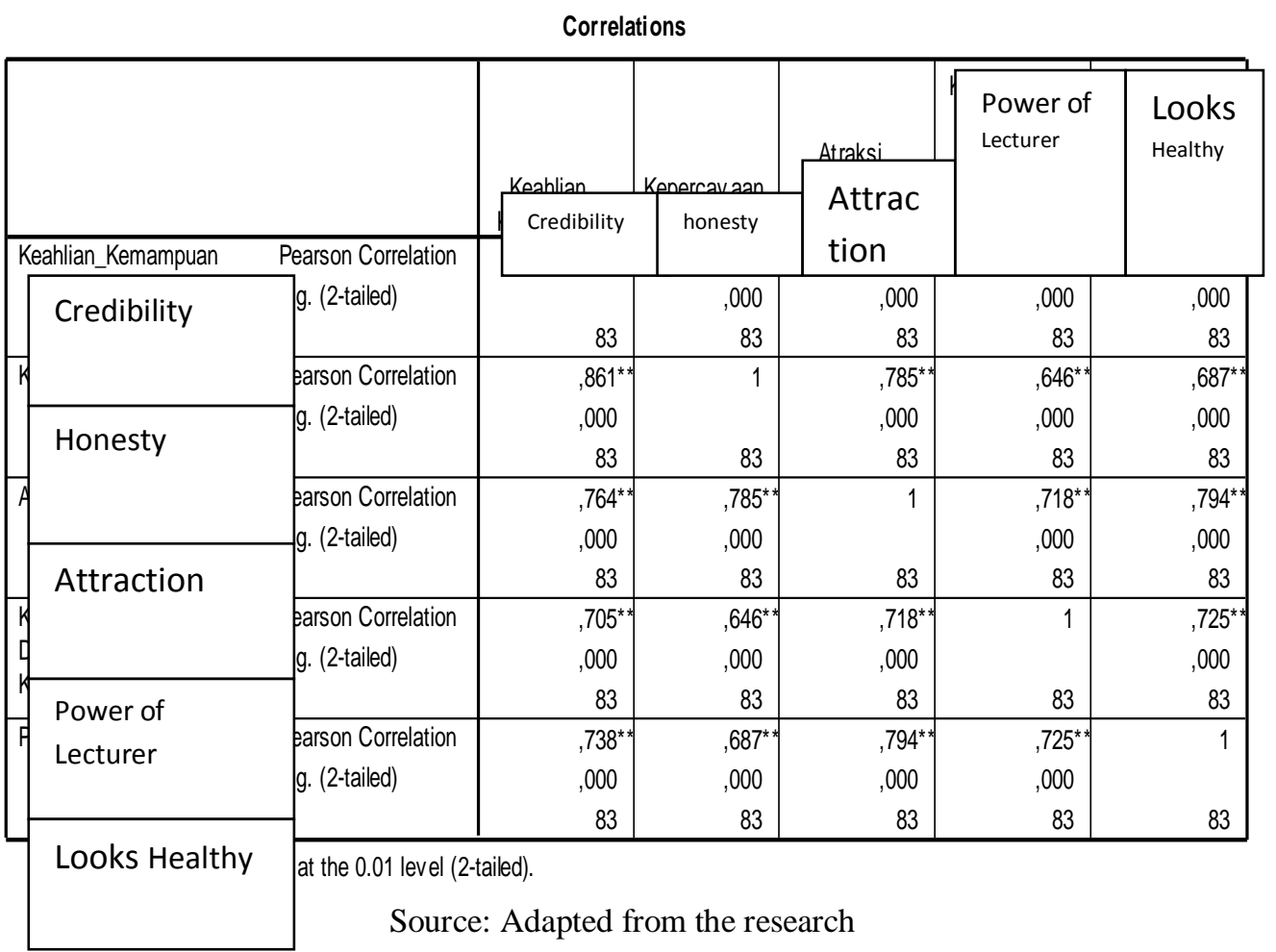

\subsection{Relationship between Communication Style with Looks Healthy}

The data were processed through the SPSS for windows obtained data that coefficient of Pearson Product Moment correlation between $\mathrm{X} 1$ with $\mathrm{Y}$ is 0.738 ; $\mathrm{X} 2$ with $\mathrm{Y}$ is 0.687 ; between $\mathrm{X} 3$ with $\mathrm{Y}$ is 0.794 ; between $\mathrm{X} 4$ with $\mathrm{Y}$ is 0.725 . The conclusion is the relationship between the ability, honesty, attractiveness and power of lecturers in the classroom have a strong enough with looks healthy.

The strongest relationship is between physical attractiveness of lecturer with looks healthy, it is in line with the concept of the Steward and Moss (2000) of the six styles of communication in an organization that is dynamic communication style so that in conjunction with the student association about healthy level of lecturers. Communication is effective when presented briefly and clearly, directly on the subject matter so it's easier to understand. In this case, it can be a physical attraction giving rise to the perception of "healthy" on the lecturer concerned.

The weakest relationship is the relationship between trust and honesty with looks healthy of lecturer. Pearson product moment coefficient show that variable correlation is weaker than the other. Honesty can be represented through eye contact, but it is better represented by a willingness to pay attention to not just listen, does not represent a healthy behavior of lecturer. 
Physical attractiveness lecturers have strong associations to the looks healthy of the lecturer. The attraction has a physical, the lecturers were considered to have a high level of health. Physical attractiveness of lecturer will create interpersonal attraction will reflect the attitude of students towards lecturers. This interest can be expressed through the dimensions that range from very like to very dislike. Proved earlier that there are components that affect student to lecturer assessment. It has been demonstrated that sex and clothing, as components of appearance, may signal differential expectations for behavior. (Johnson and Workman, 1993). In this study, elements of lecturer gender is not discussed as part of the appeal.

Each lecturer will be preferred by some students and may not be liked by the other students because of physical attractiveness is relative. Physical attractiveness can be determined because of the physical proximity means that lecturer and students, that lecturer can easily be found by students in a class apart.

Sources that influence health teacher assessments of lecturer behavior by physical attractiveness is determined by the lecturer of each college students experience. Perceptual differences can occur between students in the second semester with students in six or eight semesters of the same faculty. Perception can be determined by the situation, physical condition, mood and spontaneous student evaluations of the faculty. Elements of race and ethnicity may affect the assessment of students against lecturers as evidenced from the results of previous studies that professors' verbal responses to minority students' questions will be less complex than responses to non-Minorities. (Trujillo, 1986). That is, the ethnic elements also affect students' perceptions of the lecturers. In ITBK, ethnically diverse students as well as lecturers.

The need to build relationships with others and accepted by others hypothesized as being fundamental to the psychological need, like hunger and thirst, as well as the physical appearance of lecturer. A noble work ethic that encourages lecturer to deliver a professional who is honest and has integrity. Thus, honest means words lecturer concerned can be held and realized, the student eventually gave birth to the belief in the words and actions of lecturers. Honesty is an attitude that comes from within the faculty, which radiated through the attitudes and daily decisions. In this study turned out to be an honest attitude has no strong correlation with lecturers behaviors of health. Unlike physical attractiveness is visible, then the element of honesty can not be directly linked to a person's health behaviors.

As professionals, lecturers serve as agents of learning, development of science, technology and the arts as well as the public servants. Professional lecturer is a field work carried out on the basis of academic qualifications and educational background in accordance with the field. Qualifications views of academic education diploma according to the type, level and unit-related education courses. Lecturers should also have competence in accordance with its duties as well as having responsibility for the performance of duties of professionalism.

Through the fulfillment of the above conditions, the behavior displayed by the lecturers when teaching concluded to be a proven teaching communication styles are fairly closely correlated with health behaviors manifest. It is expected that lecturers will make students apparently healthy spirit as mentioned in the writings of the American Educational Research Journal that happens the self-fulfilling prophecy-or "expectancy effect"makes a great deal of sense in its classic form: If a teacher has high expectations for children, thinks them capable, and expects them to do well. (Goldenberg, 1992)

Power of lecturers in this study is not intended authoritarian and delivery of content in a single direction by the lecturers. In case this is indeed lecturers more dominant than the students in the class. At the college level, the balance of power need to be considered. The independence of the learners still need to be more subtle in the learning process.

The Circumstances has to bargaining for learners and lecturers stay balanced. Even the constellation of power relations, learners still have rights, but lecturers still have the "power" to reprimand students who disrupt the learning process are considered in the class. Power of lecturer stronger with legitimacy, obligations learners confirmed by clear sanctions for the infraction. But the rights of learners remain balanced, tendency rising aspirations and awareness of the rights of students to trigger sharpening demand balance of power.

Power of lecturers in this study remain in balance to maintain the quality of educational practice. Distribution of knowledge and information is increasingly widespread, as well as the orientation of the pursuit of achievement and progression of knowledge and skills to be able to dismantle the dividing line that separates learners with education. Lecturer in the corridors of power to control the class is conducive.

Through this research, the power of lecturer in teaching is considered to have a correlation with healthy behavior closely enough. Among the variables which determine students' perceptions of the level of health of the most powerful of lecturer is physical attractiveness level of health

\section{Conclusion}

Based on calculations using the computer program SPSS for windows, each of the tested variables have coefficients with numbers above 0.6. Proof of the hypothesis through Pearson product moment correlation coefficient proved Ho refused and $\mathrm{H} 1$ accepted. This means that the dependent variable can be explained 
partially independent variable and no significant effect between the two variables tested. Based on these tests, it proved "There is a close relationship between communication styles of lecturer with students' perceptions of looks healthy lecturer". Thus proved that:

1. The more lecturer has credibility in class room, the more looks healthy lecturer in the students perception.

2. The more lecturer has attractions when teaching, the more looks healthy lecturer in students perception.

3. The more lecturer has the power in the classroom the more looks healthy lecturer in students perception.

\section{ACKNOWLEDGMENT}

Author thanks to Kalbe Education Foundation - Jakarta for the financial support. Also to the lecturers and student at Institute of Technology and Business Kalbe (ITBK) as the subjects and respondents in this study. Specially to Mr. Eddy Yehuda as the consultant for the theory of communication and the content of questionnaire.

\section{References:}

[1] Babad, Elisha. Bernieri, Frank. Rosenthal, Robert. (1991) Students as Judges of Teachers' Verbal and Nonverbal Behavior. American Educational Research Journal Spring, Vol. 28, No. 1, pp. 211-234

[2] Cooper, Harris M. (1979). Pygmalion Grows Up: A Model for Teacher Expectation Communication and Performance Influence. Review of Educational Research. Summer. Vol 49, No. 3, Pp. 389-410

[3] Ghozali, Imam, 2006, Aplikasi Analisis Multivariate Dengan Program SPSS, Badan Penerbit Universitas Diponegoro, Semarang.

[4] Goldenberg, Claude. (1992). The Limits of Expectations: A Case for Case Knowledge About Teacher Expectancy Effects. American Educational Research Journal Fall. Vol 29, No. 3, Pp. 517-544

[5] Johnson, Kim K. P. and Workman, Jane E.(1993). Effect of Clothing, Sex, and Sex Role Stereotypes on Behavioral Expectations of a Preschool Child. Clothing and Textiles Research Journal. Vol.11: 1 Pp.1-6. DOI: 10.1177/0887302X9301100201

[6] Keaton, Shaughan A \& Bodie, Graham D ( 2011). Explaining Social Constructivism. Communication Teacher. Vol. 25 , No. 4. Pp. 192-196

[7] Rakhmat, Jalaluddin. (2001). Psikologi Komunikasi. Revision Edition. Editor Tjun Surjaman. Bandung : PT Remaja Rosdakarya

[8] Kurniati, Dewi. (2012). Hubungan Antara Gaya Komunikasi Guru dengan Prestasi Akademik Siswa. (Studi Korelasi Gaya Komunikasi Guru Dengan Pretasi Akademik Siswa Kelas VIII Pada Mata Pelajaran Bahasa Indonesia di SMP Negeri 2 Pakem Yogyakarta). Thesis, UPN "Veteran" Yogyakarta.

[9] Tubbs, L Steward dan Moss Sylvia. 2001. Human Comunicatin (terjemahan). Remaja Rosda karya. Bandung.

[10] Trujillo , Carla M. (1986). A Comparative Examination of Classroom Interactions Between Professors and Minority and NonMinority College Students. American Educational Research Journal Winter. Vol. 23, No. 4, Pp. 629-642

[11] Villegas, Ana María.(2007). Dispositions in Teacher Education : A Look At Social Justice.Journal of Teacher Education. Vol 58 . Pp.370-380. DOI: 10.1177/0022487107308419 